Elżbieta Zarych (1) http://orcid.org/0000-0002-4796-4419

Uniwersytet Jagielloński, Kraków

elzbieta.zarych@uj.edu.pl

\title{
Literatura oświecenia dla dzieci i młodzieży wydawana w XVIII wieku na ziemiach polskich - problemy, zjawiska, podziały, tematy
}

\begin{abstract}
Enlightenment Literature for Children and Youth Published in the $18^{\text {th }}$ Century Poland: Problems, Phenomena, Divisions, Subjects
\end{abstract}

This paper is synthetic in nature and is devoted to Enlightenment literature for children and youth published in the $18^{\text {th }}$ century in Poland. It concerns both literary studies, editing, and book history. The starting point is to look at the existing classifications and divisions of this type of literature and to verify them by rejecting the application of the modern measure to $18^{\text {th }}$-century books for young readers. Subsequently, separate determinants of the then literary works for children and youth, as well as the accompanying problems and phenomena, are presented. Typical features and functions of the content and graphic design of the items under discussion are described. Characteristics and descriptions help to define several groups which have been distinguished from the $18^{\text {th }}$-century literature for non-adult readers, in which the following sample works are discussed: 1) Collections, extracts, anthologies; 2) Teachings and models; 3) Advice from governesses; 4) French and German friends of children; 5) Role models for peasant boys; 6) Mr Campe's instructive books; 7) Parental advice and instructions. This study draws attention to issues and titles not mentioned in previous research on this literature and verifies the current state of knowledge, providing a basis for further consideration and analyses. 
Keywords: $18^{\text {th }}$-century publishing repertoires, literature for children and youth, enlightenment printing, typography and layout

Wiek XVIII' ${ }^{1}$ to wiek książki. Idee oświeceniowe oraz rozwój technik drukarskich spowodowały pojawianie się nowych drukarni, szerszą i bogatszą edytorsko ofertę wydawców, wzmożony ruch książek oraz coraz większe zainteresowanie czytelników. Zaczęto także wydawać publikacje dla dzieci i młodzieży, dotąd korzystających głównie $\mathrm{z}$ tych przeznaczonych dla dorosłych, niekiedy tylko w różny sposób dostosowywanych do wieku, wiedzy i potrzeb małego odbiorcy. Uwzględnienie tej, dotąd pomijanej, grupy czytelniczej wynikało $\mathrm{z}$ nowego postrzegania dziecka, $\mathrm{z}$ jednej strony dowartościowanego jako członka rodziny i społeczeństwa, a z drugiej uznanego za materiał do ukształtowania. Temu, by stało się rozumnym, wykształconym, cnotliwym człowiekiem i obywatelem ${ }^{2}$, służyła także literatura, odtąd coraz bardziej profilowana.

${ }^{1}$ Analizowany materiał ograniczono do XVIII wieku, nie pokrywa się więc z periodyzacją polskiego oświecenia. Jego faza schyłkowa na początku XIX wieku przynosi bowiem nowe postrzeganie dziecka, a przez to inne zjawiska i odmienną tematykę. Ze szczegółowego opisu wyłączono także utwory w duchu epoki saskiej, wydane na początku XVIII stulecia czy ukazujące się niejednokrotnie obok utworów oświeceniowych. Utwory $\mathrm{z}$ wyłączonego zakresu zostają wprowadzone tylko jako kontekst. Dokładne omówienie obu tych licznych grup to temat na osobne studia, tu wykracza poza zakres krótkiej rozprawy, nieomawiającej, co oczywiste, wszystkich utworów z XVIII wieku, ale podającej jedynie przykłady utworów z poszczególnych wyróżniających się grup.

${ }^{2}$ Zob. P. Ariès, Historia dzieciństwa, przeł. M. Ochab, Warszawa 2010, s. 192 i nn. 


\section{Problem osobności}

Kwestią podstawową w badaniu literatury dla młodego czytelnika jest odróżnienie tej grupy utworów od tych przeznaczonych dla dorosłych. W klasyfikacji zasadniczo stosuje się cztery kryteria: treści, formy, czytelnika i instytucji ${ }^{3}$. Szuka się więc wskazania określonego czytelnika w tekście (we wskazówkach odautorskich, treści, stylu), kształcie edytorskim (formacie, foncie, ilustracjach, ich liczbie, stylu, kolorystyce, sposobie umieszczenia i relacji z tekstem ${ }^{4}$ ), uwzględnia się przeznaczenie książki przez wydawcę, przyporządkowanie jej przez badaczy, biblioteki, szkoły, krytyków czy jurorów oraz odbiór czytelniczy. Te współczesne kryteria - także i obecnie w wielu przypadkach dyskusyjne i nieostre - w większości nie sprawdzają się w odniesieniu do literatury dla dzieci i młodzieży wydawanej przed wiekiem XIX, zanim ukształtował się osobny typ literatury, pisanej odmiennie i specjalnie dla młodych czytelników, wydawanej w innym niż

3 Badacze w opracowaniach dotyczących książek dla dzieci i młodzieży, w zależności od podejmowanego tematu i dziedziny, przyjmują niektóre z podanych kryteriów. Zasadniczo prace dotyczące literatury dla niedorosłych opierają się na kryterium treści i czytelnika, edytorstwa czy ilustracji - formy, recepcji - czytelnika i instytucji itd. Niejednokrotnie stosownie do prowadzonych badań łączy się też wskazane kryteria w różnych kombinacjach lub też kładzie nacisk na wybrane. Kryterium treści jest tu najbardziej sporne, a wyznaczniki przeznaczenia dla dzieci i młodzieży w obrębie niego wciąż niejednoznaczne i pełne wyjątków od reguły. Ponadto badacze stosują różne nazewnictwo odnoszące się do wymienionych kryteriów, cech i wyróżników, a także wyróżniają w nich podgrupy. Zob. na przykład E. Manasterska-Wiącek, Wstęp. O odrębności literatury dla dzieci, w: Dyfuzja i paradyfuzja w przekładach literatury dla dzieci, Lublin 2015; J. Cieślikowski, Literatura osobna, Warszawa 1985; Z. Adamczykowa, Literatura dla dzieci. Funkcje, kategorie, gatunki, Warszawa 2001; Literatura dla dzieci i młodzieży. Teoria i krytyka, red. J.Z. Białek, M. Guśpiel, Kraków 1978; J. Dunin, Ksiażeczki dla grzecznych i niegrzecznych dzieci. Z dziejów polskich publikacji dla najmłodszych, Wrocław 1991; J. Papuzińska, Inicjacje literackie. Problem pierwszych kontaktów dziecka z książką, Warszawa 1988.

4 Zob. E. Zarych, Ilustracje dla dzieci, encyklopediadziecinstwa.pl (dostęp: 10.03.2019). 
dla dorosłych kształcie, a nierzadko przez wyspecjalizowane w tego typu książkach wydawnictwa.

Dziś książka dziecięca jest osobnym fenomenem, w którym istnieje uzależnienie formy druku od odbiorcy ${ }^{5}$, a klasyfikacja tego typu publikacji ze względu na kształt edytorski jest najprostsza i budzi najmniej wątpliwości. Tymczasem w XVIII wieku te same oficyny publikowały dla czytelników w różnym wieku i o różnych potrzebach, a książki były do siebie podobne, co wynikało między innymi z możliwości ówczesnych drukarni. Większość wydanych wówczas na ziemiach polskich pozycji dla małych i młodych czytelników to książki w formacie octavo, popularnym ze względu na poręczność także w literaturze dla dorosłych ${ }^{6}$. Szata graficzna przeciętnej książki oświeceniowej była skromna i niezbyt zróżnicowana: szare czy brązowe okładki zdobiły jedynie napisy i niekiedy niezwiązane z treścią ornamenty (winiety, ramki, motywy roślinne, amorki). Kształt edytorski ówczesnych utworów dla młodych czytelników nie zależał od ich przeznaczenia i nie odbiegał znacząco od tych dla czytelników dorosłych? ${ }^{7}$. Fonty czy stosowane winiety były po prostu na stałym wyposażeniu danej drukarni i wskazywały raczej na czas powstania książki, preferencje i gust wydawcy niż na odbiorcę. Elementy słodkie, subtelne czy infantylne, postaci dzieci czy też wyglądających jak dzieci putt nie przynależały - tak jak później - do publikacji „literatury osobnej", ale po prostu do książki rokokowej. Stąd u Michała Grölla ta sama winieta na stronie tytułowej z puttem pod pochylonym drzewem jest na przykład na Teatrze dla użytku młodych [...] Mme de Genlis (1787), Arytmetyce podług reguł Jmć Pana Beniamina Hederichsa [...] dla młodzi szkolnej (1774) i komedii Panna na wydaniu (1774) Adama Kazimierza Czartoryskiego.

${ }^{5}$ J. Dunin, Książeczki dla grzecznych i niegrzecznych dzieci..., s. 5.

${ }^{6} \mathrm{~K}$. Bednarska-Ruszajowa, Uczyć - bawić - wychowywać. Książka i jej funkcja społeczna w Polsce w okresie Oświecenia, Kraków 2004, s. 112.

7 Ibidem, s. 110. 
W pułapkę współczesnego myślenia można wpaść także, kierując się w klasyfikacji gatunkiem, stylem czy treścią. W podręcznikach i opracowaniach literatury dawnej dla najmłodszych wymienia się na przykład - czytane rzekomo przez polskie dzieci w oryginale i przekładzie - Contes moraux (1761) Jeana-François Marmontela, encyklopedysty i filozofa ${ }^{8}$. Przyporządkowanie tych książek do utworów dla dzieci jest prawdopodobnie wynikiem powiązania $\mathrm{z}$ najmłodszymi formy powiastki oraz morału. Tymczasem ani publikowane w czasopismach ( $\mathrm{w}$ „Warszawskich Ekstraordynaryjnych Tygodniowych Wiadomościach”, potem w „Zabawach Przyjemnych i Pożytecznych"9), ani w tomach (od 1767 r. u Grölla w formie tanich książek $^{10}$, a u Piotra Dufoura w 1776 r. trzy tomy Powieści moralnych w przekładzie Tomasza K. Węgierskiego, w latach 1779-1780 cztery tomy Powieści moralnych z różnych autorów przez JejMć Pannę Uncy na dopetnienie jakoby powieści p. Marmontela wybranych ${ }^{11}$ i w $1794 \mathrm{r}$. trzy tomy Nowych powieści moralnych Marmontela w przekładzie anonimowym) nie były przeznaczone dla dzieci i młodzieży. Czytali je wykształceni, magnaci i szlachta, czytał król ${ }^{12}$, a tom 1 tłumacz zadedykował księciu Adamowi Czartoryskiemu, także przyszłemu czytelnikowi, jednak brak świadectw powszechnej lektury młodych. Ponadto bliższe przyjrzenie się treści i wymowie Powiastek moralnych również wyrzuca je poza lektury dla najmłodszych: ich bohaterowie

${ }^{8}$ I. Kaniowska-Lewańska, Literatura dla dzieci i młodzieży do roku 1864, Warszawa 1980, s. 33-34.

9 Z. Sinko, Powieść zachodnioeuropejska w kulturze literackiej polskiego oświecenia (Studia z Okresu Oświecenia, t. 8), Wrocław 1968, s. 223 i przyp. 45; E. Aleksandrowska, „Zabawy Przyjemne i Pożyteczne” 1770-1777. Monografia bibliograficzna, Warszawa 1999, s. 94.

${ }^{10}$ E. Rzadkowska, Francuskie wzorce polskich oświeconych. Studium o recepcji J.F. Marmontela w XVIII w., Warszawa 1989, s. 156 i 313.

11 Było to tylko nawiązanie do Marmontela, a autorem kompilacji był francuski jezuita Joseph de La Porte, nie podano tłumacza, nie wiadomo też, skąd wzięło się w tytule nazwisko panny Uncy. Z. Sinko, Powieść zachodnioeuropejska..., s. 273, przyp. 68.

12 E. Rzadkowska, Francuskie wzorce..., s. 75, 148-156. 
(akcja nierzadko osadzona w scenerii antyku czy Orientu) to głównie dorośli „po przejściach”, wymowa moralna często jest dwuznaczna, a same utwory według najnowszych badań nie służą nauce moralnej, ale są rodzajem przewrotnego żartu salonowego ${ }^{13}$.

Trzeba pamiętać, że wiek XVIII jest przełomowy dla książki dla dzieci i młodzieży, a oświecenie to epoka, którą Ryszard Waksmund nazywa „starożytnością literatury dla dzieci" ${ }^{\text {". }}$ Z jednej strony to paradoksalnie ,archaiczne początki” tej literatury, a z drugiej jej okres klasyczny, w którym wykształcają się pierwsze zasady i konwencje tworzenia dla młodego czytelnika, od tej pory zawsze będące dla niej punktem odniesienia ${ }^{15}$. Stąd do dziś pisuje się $\mathrm{w}$ duchu oświeceniowym (pedagogicznie, moralizatorsko), sięgając do ówczesnych gatunków i rozwiązań (przez co ten sposób pisania uważa się często za właściwy literaturze dla dzieci), a także czytuje się wiele klasycznych obecnie, a powstałych wówczas utworów, które ocenia się z perspektywy ich późniejszej recepcji. Dlatego też klasyfikuje się osiemnastowieczne utwory, takie jak Przypadki Robinsona Krusoe Daniela Defoe (1719; tłum. J.C. Albertrandi, Warszawa: Michał Gröll, 1769) czy Podróże kapitana Guliwera w różne kraje dalekie Jonathana Swifta (1726; tłum. anonimowe ${ }^{16} \mathrm{z}$ przeróbki francuskiej, Supraśl: Drukarnia Bazylianów, 1784 ${ }^{17}$, jako lektury dla dzieci i młodzieży ${ }^{18}$. Określając przynależność tych fantastycznych

13 Ibidem, s. 77.

14 R. Waksmund, Nie tylko Robinson, czyli o oświeceniowej literaturze dla dzieci i młodzieży, Warszawa 1987, s. 5.

15 Ibidem.

${ }_{16}$ Prawdopodobnie autorem przekładu jest prefekt drukarni Melecjusz Ossuchowski, zob. na przykład: В. Пазднякоў, Асухоўскі Мялецій (Ossuchowski Meleсjusz), w: ВКЛ эниььклапедья, http://vkl.by/articles/2307 (dostęp: 30.08.2019).

17 Był to utwór Desfontaines’a. Polskiego przekładu doczekała się w 1787 roku także francuska kontynuacja dzieła Swifta, z tą różnicą, że tam głównym bohaterem jest Jean Gulliver, syn Lemuela, a w polskiej wersji, jak w angielskim oryginale, on sam. Zob. Z. Sinko, Powieść angielska osiemnastego wieku a powieść polska lat 1764-1830, Warszawa 1961, s. 24-28.

18 Zob. na przykład: R. Waksmund, Nie tylko Robinson..., s. 50-110; A. Wojnarowska, Kultura i literatura. O genezie i rozwoju polskiej literatury dla najmłodszych, 
i przygodowych utworów, patrzy się bowiem na nie z perspektywy XXI wieku i dzisiejszych czytelników, z ich wiedzą i gustami, a jednocześnie nakłada się na to kontekst 300 lat funkcjonowania różnego rodzaju adaptacji i przeróbek. Podobne wątpliwości budzi przyporządkowanie do ówczesnych książek dla dzieci i młodzieży na przykład Inkasów czyli zniszczenia Państwa Peru Marmontela (1779; 2 tomy, tłum. Stanisław Kłokowski, Warszawa: Michał Gröll, 1781, wyd. 2 - Lwów 1794). Oczywiście mamy świadectwa lektury tych książek przez ówczesnych młodych, choćby Defoe przez Juliana Ursyna Niemcewicza ${ }^{19}$ czy Inkasów Marmontela przez Adama Mickiewicza ${ }^{20}$, ale trzeba pamiętać, że utwory te nie powstały dla tej grupy czytelniczej, ale dla szerokiego kręgu. Były one jedynie przez tę grupę - jak to ujmuje Krystyna Bednarska-Ruszajowa - „przechwytywane” jako atrakcyjne ${ }^{21}$. Utworów tych nie można więc badać jako przynależnych do osiemnastowiecznej literatury dla dzieci i młodzieży, ani nawet dwuadresowej, ale jedynie elitarnie, jako lektury wybitnych młodych jednostek, najczęściej dobrze urodzonych. Podobnie jest w przypadku bajek Ezopa czy Krasickiego, utworów fantastycznych czy jarmarcznych ${ }^{22}$, romansów rycerskich, awantur arabskich itd. Tematyka bajkowa, zwierzęca, przygodowa itd., będąca dzisiaj wskazówką przeznaczenia dla najmłodszych, jest myląca i narzuca ówczesnemu czytelnictwu oraz rynkowi wydawniczemu XVIII wieku dzisiejsze reguły. Tymczasem to utwory dla szerokiego grona czytelników, głównie dorosłych ${ }^{23}$, które z czasem poszerzyły zasięg lub zmieniły adresata i zawędrowały (ze względu na określone cechy) do pokoju dziecięcego. Za przeznaczone dla najmłodszych

s. 74, http://www.bwmp.up.krakow.pl/wp-content/uploads/2016/10/Wojnarowska. pdf (dostęp: 11.03.2019).

19 Z. Skwarczyński, „Podróże napowietrzne” Juliana Ursyna Niemcewicza, „Prace Polonistyczne" 21 (1965), s. 71-74.

${ }^{20}$ Czytał ją, według relacji brata, w pierwszej klasie, po bajkach Krasickiego. E. Rzadkowska, Francuskie wzorce..., s. 274-275.

${ }^{21} \mathrm{~K}$. Bednarska-Ruszajowa, Uczyć - bawić - wychowywać..., s. 122.

${ }_{22}$ Zob. rozważania Waksmunda: R. Waksmund, Nie tylko Robinson..., s. 6-54.

${ }^{23}$ Od wieków dzieci czytały lub czytywano im utwory dla nich nieprzeznaczone, a cenione przez dorosłych. 
można uznać jedynie ich wersje dostosowane i opatrzone wskazówką o przeznaczeniu, na przykład dwujęzyczne wydanie Ezop w wesołym humorze, albo wybrane jego bajki, z naukami moralnymi i wierszykami, tudzież najpiękniejsze bajeczki Fedra, Pilpego i pana de La Motte [...] (Michał Gröll, 1769) ${ }^{24}$. Osobno rozpatrywane powinny być też utwory napisane $\mathrm{z}$ myślą o dorosłych, a wykorzystywane w edukacji, wystawiane w teatrach szkolnych itp.

W klasyfikacji ówczesnych książek przeznaczonych dla dzieci należy więc kierować się przede wszystkim zamierzeniem autora oraz wydawcy, jednoznacznym wskazaniem na tego typu czytelnika. Zwłaszcza że - jak pisze Bednarska-Ruszajowa - w oświeceniu nie istniał adresat potencjalny, ale zawsze założony (przez autora, wydawcę, drukarza), o czym informację umieszczano w tytule, przedmowie, treści itd. ${ }^{25}$ Kryterium to jest więc w przypadku utworów osiemnastowiecznych podstawowe, istotny jest też wyznacznik stosowany współcześnie, a oparty na dawnym wzorcu: wiek głównego bohatera czy bohaterów, a także odpowiednie dla danego wieku treści i przesłanie; oczywiście w stosunku do ówczesnych dzieci i nastolatków, nie zaś dzisiejszych.

Z drugiej strony trudno uznać jednoznacznie za książki dla niedorosłych czytelników takie, w których przeznaczenie dla dzieci czy młodzieży pojawia się w tytule, natomiast nie wskazuje na nie do końca treść. Są to najczęściej wszelkiego rodzaju rady, exempla i historie, z których - jak sądzą autorzy i wydawcy - wszyscy czytelnicy, w tym także ci młodzi, którzy powinni się uczyć życia, mogą wyciągnąć jakąś naukę. Przykładem jest choćby zbiór korespondencji sąsiadów-szlachciców Polak sensat w liście, w komplemencie polityk, $w$ mowach statysta, na przykład dany szkolnej młodzi Wojciecha Bystrzynowskiego (Lublin: Drukarnia Jezuitów, 1730). Dla szerokiego grona czytelników (jak podano w przedmowie: dla każdego poczciwego człowieka), mimo umieszczenia w tytule „młodzi”, jest też przeznaczony zbiór wykładów o świecie i cnocie autorstwa Eustachego

24 Przeznaczenie dla dzieci odnotowane we wstępie.

${ }^{25}$ K. Bednarska-Ruszajowa, Uczyć - bawić - wychowywać..., s. 205. 
Le Noble Szkoła świata albo nauka jednego ojca dana synowi swemu, jak ma żyć i postępować wświecie, na rozmowy podzielona [...] dla pożytku powszechnego młodzi polskiej [...] (oryg. 1715; pol., Królewiec: Jan Henryk Hartung, t. 1 - 1755, t. 2 - 1761; wznowienie całości - Michał Gröll, 1778) w przekładzie Mikołaja Rudominy-Dusiackiego ${ }^{26}$. Tego typu książki należy wydzielić jako osobną grupę, jako przeznaczone dla różnych czytelników, w tym i młodych, jednak trudno stwierdzić, czy i w jakim zakresie sięgali oni po te utwory.

Jeszcze jedną budzącą wątpliwości grupę stanowią teksty standardowo przypisywane odbiorcy dziecięcemu, a skierowane raczej do rodziców i wychowawców, w których to utworach dzieci są jedynie tematem i przedmiotem nauk czy obserwacji. Należy do nich choćby znany wiersz zawierający dawne metody wychowawcze Różḋk $a$ D Duch Święty dziateczki [...] Znajdujemy go w XVIII wieku w tomie Nauka chrześcijańska katolicka rzymska prawdziwa (Wilno: Drukarnia Akademicka Societatis Jesu, 1729) ${ }^{27}$, jak i Nowy elementarz duchowny dziecinnego ćwiczenia z przydatkiem nabożeństwa porannego, wieczornego i inszych modlitw oraz z wykładem mszy świętej i katechizmem, teraz nowemi wokabulami przyozdobiony (Kraków: Drukarnia Akademicka, 1769). Takie utwory były dość popularne w XVII wieku, ale wznawiano je i publikowano w tym duchu nowe (choć rzadziej) także w kolejnym stuleciu ${ }^{28}$. To raczej wsparcie dla rodziców i potencjalne ostrzeżenie dla dzieci niż lektura dla najmłodszych.

${ }^{26}$ Jak wyjaśnia autor dzieła w przedmowie, Le Noble napisał trzy tomy, z czego w Polsce ukazały się dwa, gdyż zrezygnowano z opisu „przyjścia do stanu fortuny w stanie politycznym, [...] w stanie skarbowym, [...], w stanie kupieckim", bowiem te nie stosowały się do obyczajów polskich.

${ }^{27}$ Jak zauważa Margarita A. Korzo, podobny utwór znajdujemy już wcześniej, w 1692 roku, w tomie Nauka i skarb młodym dziatkom, po Kolędzie, a ich powstanie może się wiązać także z wyprawami po rózgi podczas „gregorianek” czy z Zielonymi Świątkami. Zob. M.A. Korzo, Elementa Pverilis Institutionis (Kraków 1692) przyczynek do historii elementarzy polskich, „Biblioteka” 20 (2016), s. 77-78.

${ }_{28}$ Podobnie na przykład wznawiana w XVIII wieku (Kraków [s.n.] 1759), a pochodząca z poprzedniego stulecia, napisana pod pseudonimem „Adryan Krzywodębski” instrukcja karania zatytułowana Chłopiec wyćwiczony chłopcom gnuśnym, 


\section{Podziały, cechy i funkcje}

Opracowujący temat literatury dla dzieci i młodzieży, która ukazała się w Polsce w oświeceniu, starają się ją podzielić według różnych kategorii. Najczęstszy jest podział na utwory tłumaczone (a w ich obrębie francuskie i niemieckie) oraz rodzime (głównie antologie zawierające utwory polskich poetów). Taki podział występuje choćby w monografii Izabeli Kaniowskiej-Lewańskiej Literatura dla dzieci i młodzieży do roku 1864 (1980), będącej podstawowym źródłem dla zajmujących się literaturą dla najmłodszych ${ }^{29}$. Jednak, jeśli przyjrzymy się bliżej tym utworom, podział ten okazuje się bezzasadny. Rzeczywiście większość utworów dla małych czytelników to przekłady z francuskiego, będącego wówczas językiem ludzi wykształconych, ale z przekładami z niemieckiego sprawa nie jest tak jasna, gdyż niejednokrotnie bywają one zapośredniczone przez francuski albo wręcz są utworami (mniej lub bardziej zmienionymi) francuskimi. Podobnie bywa $z$ tekstami uważanymi za polskie. Są też utwory francuskie, które dotarły do nas przez przekład z niemieckiego. Niejednokrotnie trudno jest określić źródło, autora czy język przekładu; brak skrupulatności w ich podawaniu wynikał z tego, że od tego, kto go napisał czy przełożył, ważniejsza była wówczas zawartość i wymowa tekstu. Dochodzi też odmienna filozofia przekładu, często dość swobodnego, udomowionego, na granicy adaptacji. Podział ze względu na język pochodzenia uniemożliwia także ówczesne zamiłowanie do tworzenia kompilacji czy antologii mieszających utwory rodzime, tłumaczone wprost i zapośredniczone, adaptowane w różny sposób i w różnym zakresie.

Równie trudno byłoby wprowadzić podział ze względu na gatunek, cechą charakterystyczną utworów osiemnastowiecznych jest bowiem

leniwym, kujonom i domatorom dla ćwiczenia chłosty dobrej, według opisania niżej mianowanych artykułów, szczerze i uprzejmie na zawsze życzy i winszuje (Kraków [s.n.] 1680; nieznane wyd. 1).

29 Zob. na przykład: J. Konieczna, Rynek wydawniczy książki dziecięcej w zaborze rosyjskim $w$ XIX i w początkach XX wieku, „Sztuka Edycji” 1 (2013), s. 57. 
synkretyzm. W wielu tomach - nie tylko w zbiorach - znajdujemy utwory różnej przynależności, opowiadania, baśnie, utwory poetyckie (poematy, bajki, pieśni) i teatralne, mowy, zagadki itd. ${ }^{30}$ Zróżnicowanie dotyczy także stylu, idącego to w stronę beletrystyki, służącej często pedagogice, to publicystyki ${ }^{31}$. Utwory dla niedorosłych czytelników w tej epoce są więc często mieszanką utworów pochodzących z różnych języków, różnych gatunków, stylów, treści. Służy to z jednej strony urozmaiceniu lektury (co w czasach, gdy książka była wciąż dla wielu kosztownym nabytkiem, było wielką zaletą), a z drugiej - jej wielofunkcyjności.

Niezwykle ważną kwestią, jeśli nie najważniejszą, jest bowiem funkcja publikacji. Oświecenie, opierając się na poglądach pisarzy starożytnych (Arystotelesa, Horacego, Cycerona, Kwintyliana), stworzyło wytyczne dotyczące roli literatury, która miała uczyć (docere), wzruszać (movere), bawić/dostarczać przyjemności (delectare), a także przynosić pożytek (prodesse). Funkcje poznawcza, wychowawcza (ideowo-moralizatorska ${ }^{32}$ ) i rozrywkowa ${ }^{33}$ pożytecznej literatury najwyraźniej widoczne są w utworach skierowanych do czytelnika niedorosłego, który stał się obiektem kształtowania, a dydaktyzm takiej literatury do dziś jest podstawowym wyróżnikiem utworów osobnych $^{34}$. Literatura miała dostarczać dzieciom i młodzieży wiedzy o świecie, wskazywać cele, wzorce i zasady właściwego postępowania oraz przekonywać do stosowania się do nich, stać się użyteczną nauczycielką życia i cnoty ${ }^{35}$. Celom tym podporządkowana była

${ }^{30}$ Nisko w hierarchii gatunków są utwory pełne fantazji, będące jedynie przygodą dzieciństwa i rozrywką lub podporządkowane funkcji poznawczej i dydaktycznej.

31 R. Waksmund, Nie tylko Robinson..., s. 173.

32 Określenie Anny Żbikowskiej-Migoń. (Dzieje książki i jej funkcji społecznej. Wiek XVIII, Wrocław 1987, s. 111).

33 Zob. K. Bednarska-Ruszajowa, Uczyć - bawić - wychowywać..., s. 194/195. Autorka nazywa je jeszcze inaczej: poznawczo-utylitarna, ideowo-wychowawcza, rozrywkowo-estetyczna, dodając z perspektywy współczesnej funkcje informacyjną, kulturową, perswazyjną i polityczno-agitacyjną.

${ }^{34}$ R. Waksmund, Nie tylko Robinson..., s. 5.

35 A. Smuszkiewicz, Literatura dla dzieci, Poznań 2015, s. 23; K. Bednarska-Ruszajowa, Uczyć - bawić - wychowywać..., s. 194-195. 
forma i treść pożytecznych, obyczajnych, stosownych i uciesznych utworów. Owa wielofunkcyjność literatury wyklucza jednak także podział wydawanych wówczas utworów dla dzieci i młodzieży ze względu na funkcje.

Kompilacyjność, synkretyzm, wielotematyczność i wielofunkcyjność sprawiają, że utwory tego czasu - pod wieloma względami podobne - niezwykle trudno jest podzielić, a brak prostych rozwiązań każe szukać bardziej złożonych. Tym, co wyraźnie wyróżnia wiele tekstów, jest adresat: są książki skierowane do dziewcząt i do chłopców, a także niejednokrotnie do określonej warstwy społecznej. Czynnikiem wyróżniającym jest też osoba autora: jego pochodzenie, wykształcenie, zajęcie czy poglądy, istotnie rzutujące na kształt i tematykę dzieła, a także postawa, jaką prezentuje. Te dwa podstawowe wyznaczniki - autor i adresat - łączą się w różny sposób z tematyką dzieła, jego formą, ujęciem tematu czy językiem. Skrzyżowanie tych kategorii pozwala wyróżnić kilka podstawowych grup wśród książek oświecenia wydanych w XVIII wieku na ziemiach polskich z myślą o niedorosłych czytelnikach.

\section{Zbiory, wypisy, antologie}

Utwory tej grupy z jednej strony nawiązują do barokowych sylw, z drugiej - spełniają założenia dobrej oświeceniowej książki dla dzieci i młodzieży, a więc łączącej w jednym tomie rozmaitość i bogactwo treści oraz realizującej wszystkie ważne funkcje. Wśród tych zbiorów są zarówno tomy w całości tłumaczone, zawierające teksty autorów rodzimych i obcych, jak i takie, których autorów i pochodzenie trudno określić.

Przekładem z francuskiego są wydane w 1787 roku w Warszawie u Dufoura dwa tomy zatytułowane Wyborne zdania i myśli, czyli Apophtegmata i powieści starożytnych mężów sławnych wyjęte z Plutarcha, Diogenesa Laercjusza, Eliana, Ateneusza, Stobea, Makrobiusza i innych Mikołaja Perota d’Ablancourta w przekładzie kasztelana 
mazowieckiego Franciszka Podoskiego. Oprócz tekstów nawiązujących do tradycji parenetycznej ${ }^{36}$ znalazły się w nich też, co ciekawe, zapewniające rozrywkę i pełne fantazji bajki Perraulta. Charakter parenetyczno-edukacyjny ma także - zawierający 48 utworów narracyjnych wierszem i prozą (anegdoty, bajki, sielanki, powieści wschodnie) o problematyce moralnej - tom Biblioteka dziecinna. Dzieło dla rozrywki młodych umystów, prostowania serc do cnoty i odrażenia od występków, z pisarzów dawnych i tegoczesnych zebrane proza $i$ wierszem $z$ francuskiego przełożone (Warszawa: Drukarnia J.K.M. i Rzeczypospolitej, $1783^{37}$; wyd. 2 - 1796) w przekładzie związanego z Rzeszowem pijara Kajetana Karniewskiego.

Trzy spośród zbiorów przełożonych z francuskiego tytułem sugerują tematykę sentymentalną. Jednakże i w Zbiorze powieści moralnych wyjętych $z$ dzieł różnych najpóźniejszych tego wieku autorów dla dzieci przez pana Gessnera, z których się zabawić i cnotę mitować moga (brak tłum., Warszawa: Drukarnia Księży Misjonarzy, 1790), i w Zabawce serc czulych. Z francuskiego przez Karolinę Czermińska starościankę drohomyślską (Kraków: Ignacy Grebel, 1785), prócz utworów Gessnera, znajdują się też zgoła niesentymentalne powiastki, między innymi Marmontela, zaprzysięgłego wroga filozofii Rousseau. Wpływy szwajcarskiego poety widoczne są także w anonimowym tomie Bukiet dla matek i dzieci, albo wdzięki dzieciństwa i rozkosze macierzyńskiej miłości (Warszawa: Piotr Zawadzki, 1794). Trudno stwierdzić, czy zawarte w nim czułe refleksje, „idyllki” prozą i różne maksymy to wolne przekłady czy utwory własne.

Za pośrednictwem francuskiego udostępniono polskim czytelnikom służący ich edukacji [Wybór] krótkich powieści, anekdotów, bajek, komedii, rozmów itd., przystosowanych do użycia i pojęcia dzieci obojej płci wszelakiego wieku [...] (Warszawa [s.n.] 1792). Jak podaje podtytuł, jego „wszystkie prawie kawałki są wyjęte i przełożone z obcych języków na język francuski", trudno jednak jednoznacznie

36 Zbiór wykorzystywano w kształceniu uczniów Szkoły Rycerskiej.

37 Rok po śmierci tłumacza. 
określić pierwotne języki i źródła owych wyimków. Mieszankę utworów polskich i przełożonych (najczęściej z francuskiego ${ }^{38}$ ) z najważniejszego polskiego czasopisma oświeceniowego zawiera zbiór Zdrowe rady dla młodzieży $z$ "Monitora” wybrane i dla powszechnego pożytku osobno przedrukowane (Warszawa: Mitzler de Kolof, 1777). Także liczne antologie na pograniczu literatury pięknej i podręcznika, napisane przez nauczycieli - niezależnie od polskich autorów na okładce - trudno uznać za rodzime ${ }^{39}$. Nazwiskiem Antoniego Prokopowicza, pijara i nauczyciela w krakowskim kolegium i seminarium pijarskim, podpisane są trzy utwory. Pierwszy to Nauka z przypadku, czyli moralne wierszem powieści do obyczajów młodzi przystosowane, wydana w 1784 roku anonimowo w Krakowie u Grebla, a przypisywana (na co wskazywał sam Prokopowicz) Maksymilianowi Popławskiemu ${ }^{40}$. Podobnie jak drugi tekst - Usposobienie do dalszych nauk [...] - Nauka... została napisana dla jednego z wychowanków, kasztelanica sądeckiego Alojzego Andrzeja Ankwi$\mathrm{cza}^{41}$. W wierszowanej opowieści mali i naiwni bohaterowie ze szlacheckich rodzin (Wojtuś i Karol) wychodzą na spacer i tu przyroda (za Rousseau) dostarcza okazji do nauki i wychowania: nie można nauczyć śpiewać słowika i nie zniszczyć u rody schwytanego motyla, co wyjaśnia im mentor, porównując tresurę ptaków do wychowania dzieci, opowiadając o starości i opatrując każdy wiersz Horacjańską maksymą $^{42}$. Prokopowicz stworzył również utwór dla dziewcząt kształcących się u prezentek krakowskich zatytułowany Wypisy $z$ ksiag i rękopisów (druk. Anny Dziedzicki i Sukcessorów, 1790), w którym zamieścił fragmenty własnych przekładów, a także bajki Ignacego Krasickiego, wiersze Elżbiety Drużbackiej i Wincentego

${ }^{38}$ Na s. 18 (z 52) pojawia się - mogące wskazywać na pochodzenie - objaśnienie francuskie.

39 Tak klasyfikuje je na przykład I. Kaniowska-Lewańska, Literatura dla dzieci i młodzieży..., s. 38-41.

40 R. Waksmund, Nie tylko Robinson..., s. 163.

${ }_{41}$ Przyszłego arcybiskupa lwowskiego oraz prymasa Galicji i Lodomerii.

42 Zob. R. Waksmund, Nie tylko Robinson..., s. 164. 
Ignacego Marewicza ${ }^{43}$. Podobnie mieszany jest Wyborny zbiorek historyjek, bajeczek, rozmówek, medytacji i innych rzeczy roztropnych do poczciwej rozrywki i nauki służacych, stworzony przez dyrektora gimnazjum toruńskiego i nauczyciela języka polskiego Jana Jakuba Dzwonkowskiego (Gdańsk: Thomas Johannes Schreiber, 1757). Wprawdzie zawiera on utwory Jana Kochanowskiego, ale nie należy zapominać, że nie bez powodu ma też podtytuł „najwięcej z francuskiego na polski język przetłumaczonych".

Od tych literackich antologii odróżnia się Zbiór przystojnych rozrywek, czyli sposoby uczciwe i ucieszne do przystojnego rozweselenia umysłu na użytek powszechności, a szczególnie dla młodzi wiejskiej parafialnej, zebrany przez proboszcza korkożyskiego Józefa Legowicza, wydany w Wilnie u księży bazylianów w 1783 lub 1784 roku (data wnioskowana z imprimatur z 1783 r.) ${ }^{44}$. Wprawdzie zawiera on wiadomości naukowe i pseudonaukowe oraz ma wymowę moralizatorską, ale - być może ze względu na przeznaczenie dla „młodzi wiejskiej parafialnej" - ma charakter głównie rozrywkowy, nierzadko rubaszny, i pełen jest tekstów lekkich: epigramatów, fraszek, zagadek, dowcipnych wierszyków, gier dla dzieci.

Ciekawy jest zbiór nauczyciela wrocławskiej szkoły realnej Daniela Vogla zatytułowany Polska ksiażka do czytania, to jest zbiór nauk i zabawek filologicznych, na pożytek i snadniejsze pojęcie polskiego języka dla młodzi kwitnacej Szkoły Realnej Wrocławskiej [...], wydany w 1768 roku we Wrocławiu u Jana Fryderyka [Johanna Friedricha] Korna (wyd. 2 - 1785). Niemiecki tytuł Polnisches Lesebuch; das ist, Sammlung von philologischen Lehren und Vergnügungen für die Anfünger der polnischen Sprache [...] wskazuje, że są to czytanki dla początkujących w języku polskim, którzy - jak pisze we wstępie autor - mają problem z dostaniem odpowiednich książek do nauki kochanego języka. Wydanie jest dwujęzyczne, polskie słowa opatrzone są

${ }^{43}$ Dołączył je do podręcznika zatytułowanego Sposób nowy, najłatwiejszy pisania i czytania razem dla panienek. Z przypisami dla nauczycielek...

${ }^{44}$ Estreicher podaje datę 1797 (Bibliografia polska, t. 21, Kraków 1906, s. 147). 
przypisami tworzącymi na dole strony polsko-niemiecki słowniczek. Znajdują się tu teksty z zakresu religii, przyrody, geografii, a także opowiadania z Pisma Świętego, bajki dydaktyczne (np. o pastuchu i lwie) i fantastyczne (m.in. francuskie baśnie Piękna i Bestia i Trzy życzenia), sielanki prozą (np. o Myrtylu i Dafne, powiastki, anegdoty (w tym o znanych Polakach) i wskazówki praktyczne (np. jak korzystać z map). Część utworów autor zapewne napisał sam, część przełożył, część adaptował; brak podanych źródeł.

\section{Nauki i wzorce}

Popularnymi formami dydaktycznej literatury dla niedorosłych, służącymi wychowywaniu i prezentowaniu właściwych postaw, są wszelkiego rodzaju zbiory porad i wzorów osobowych. Również w literaturze XVIII wieku stanowią one sporą grupę. Można wyróżnić wśród nich popularne w czasach saskich utwory związane z nauką Kościoła; wznawiano je także w oświeceniu. Należą do nich wybrane historie z Biblii niosące naukę dla niedorosłych, jak na przykład Dwakroć pięćdziesiąt $i$ dwie wyborne Pisma Świętego historie ze Starego i Nowego Testamentu, dla młodzi chrześcijańskiej [...] Johanna Hybnera (Hübnera), geografa, nauczyciela, rektora szkoły w Hamburgu (niem. 1714 i 1731, pol. Królewiec 1749 i $1766^{45}$ ), postylle (np. Postylla dla dziatek, albo młodzi chrześcijańskiej Christiana Langhansa, tłum. z niem. Krzysztof Haberkant, Królewiec 1745), a także wybory pouczeń pod patronatem świętego (np. Delicje dziecinne. Ś. Mikołaj biskup mireński i jedna serca ich pociecha kolęda duchowna [...] ${ }^{46}$

45 Pierwsze wydanie sfinansował Jan Henryk Hartung, drugie - jego spadkobiercy. W 1760 roku tekst ukazał się też w Gdańsku w języku niemieckim. Opiekę nad edycją roztoczył Krzysztof Celestyn Mrongowiusz.

46 Stąd, jak głosi długi tytuł, uczyła: „[...] I w pospolitości wszytkich ludzi, a osobliwie też w lata i w grzechy obstarnych, jak się na duszy odrodzić, jak Pana Boga jedyne nieba i ziemie i wszystkiego stworzenia Delicje poznawać i kochać sku- 
ks. Macieja Frączkiewicza, Kraków: Drukarnia Akademicka, 1748). Niejednokrotnie tego typu utwory skierowane były do uczniów szkół parafialnych, do pochodzących z niższych stanów dzieci, ale i reprezentujących podobny poziom wiedzy dorosłych, na przykład Akademia dziecinna, albo zbiór nauk różnych na świecie zwyczajnych [...] dla wygody młodzieży bądź szkolnej, bądź domowej osobliwie parafialnej krótko po polski [!] zebrany [...] (Wilno 1761) czy Lac rationabile mleko duchowne, to jest pożyteczna i potrzebna nauka chrześcijańska, dziatkom, i ludziom dorostym, którzy dla stabszego rozumu jeszcze sa niemowiatkami w Chrystusie, przedłożona i krótkim wykładem objaśniona, z przydatkiem różnych modlitw duszom nabożnym pewnego czasu zwyczajnych (Wrocław: Drukarnia Akademicka, Jezuicka, 1729, wyd. 2 - Lwów 1733).

W epoce oświecenia dla małych i młodych czytelników publikowano utwory służące rozwojowi pożądanych cnót i umiejętności, przykładem jest podzielona na lekcje dwujęzyczna Ksiązka dla mło$d z i^{47}$, albo wyobrażenia ogólne i odistoczenia rzeczy, w których dzieci powinny być ćwiczone [...] - Le livre des Enfants, ou idées générales et définitions des choses, dont les Enfants doivent être instruits [...] (Warszawa: Michał Gröll, 1768/1769, 1774, 1784) czy będące przekładem $\mathrm{z}$ francuskiego Dzieła X. Baudory, dla szlachetnej młodzieży wielce użyteczne, do odkrycia i wydoskonalenia przymiotów im potrzebnych, we czterech rozprawach zamknięte (Lublin: Drukarnia Trynitarzy, 1785). W drugim z utworów, autorstwa ks. Josepha Du Baudory'ego (1710-1749), jezuity, wykładowcy w paryskiej szkole Louis-le-Grand, zawarto rozprawy (podzielone na mowy) w przekładzie ks. Remigiusza Ładowskiego, poświęcone kolejno: wadom młodego wieku, przymiotom umysłu, zasługom w służbie wojskowej oraz czterem etapom

tecznych sposobów nauczająca. Imieniem tegoż cnotami i życiem od dzieciństwa świątobliwym Doktora a szczodrobliwego we wszytkich potrzebach dusznych i doczesnych Patrona [...]".

${ }^{47}$ We wznowieniach z 1774 i 1784 roku w tytule zastąpiono wyraz „młodzi” słowem „dzieci”. „Młodź” pojawia się także w wydaniu polsko-włoskim drukarni Ogińskiego (Słonim 1778). 
życia ludzkiego; kompozycja ta jest celowa i planowa. Wypowiadają się tu sędziowie, szlachetni mężowie, którzy sami przezwyciężyli ułomności dzieciństwa, jak niedbalstwo, żywość, lekkomyślność i powolność, a teraz roztrząsają je, służąc pomocą i wskazówkami słuchaczom w „formowaniu Młodości ślepej i niedoskonałej”. Na bazie przezwyciężonych słabości można kształtować pożądane cechy, stąd kolejna część poświęcona jest właśnie bystrości rozumu, „dowcipowi wysokiemu”, dobrej pamięci, wiedzy, wybornemu gustowi i wyrobionym opiniom. A że najwyższą cnotą jest służba dla ojczyzny, nic więc dziwnego, że w części trzeciej - która już jednoznacznie wskazuje na to, że książka skierowana jest do chłopców wyższych stanów - ukazane zostały zasługi oficerów różnych wojsk, a wraz z nimi między innymi sława, męstwo, honor, umiejętności i użyteczność dla kraju. W ostatniej części szczegółowo zostają wyjaśnione i sposób służenia ojczyźnie, i powinności w różnym wieku.

Ciekawą grupę tworzą kształtujące właściwe postawy pièces morales, także z negatywnymi wzorami osobowymi. Są wśród nich zarówno utwory wierszowane, jak i prozą. Rymowana jest na przykład bajeczka-sielanka Dziecię poprawione Guillaume'a-Antoine’a Lemonniera (1779), przełożona $\mathrm{z}$ francuskiego przez Adama Naruszewicza, opowiadająca o Antosiu, który najpierw nieświadomy wyrządzanej krzywdy oskubał chroniącego się w chacie przed zimnem ptaszka, a po wykładzie ojca, mądrzejszy, nawrócony i skruszony, autodydaktycznie powiesił w chacie zwłoki jako nieco makabryczną wychowawczą przestrogę na resztę swego życia. Z utworów prozą warto wymienić wydane w supraskiej Drukarni Bazylianów, anonimowo i bez tłumacza, dwa tomy Wychowańca natury (cz. 1 - 1785, cz. 2 - 1786). Autorem tej książki, noszącej w oryginale tytuł L'Élève de la nature (1766), jest Gaspard Guillard de Beaurieu (1728-1795), a przełożył ją białoruski prefekt drukarni Melecjusz Ossuchowski. Rok później wydano w Supraślu tekst będący wycinkiem tego utworu - Kawaler i panienka oboje $w$ młodości źle wychowani [...] (1786). Obie pozycje nawiązują do krytykowanej koncepcji „dziecka natury” Rousseau, inspirującej wiele utworów, w tym choćby Imirce, ou la Fille de la nature Henri Josepha Du Laurensa czy Podolankę wychowang w stanie natury [...] Michała Dymitra 
Krajewskiego. Podolanka ukazała się w 1784 roku, rozpoczynając tak zwany „spór o Podolankę”. Zapewne na fali popularności tej ostatniej książki i w ogniu dyskusji o dobrym i złym wychowaniu bazylianie podjęli decyzję o wydaniu obydwu wspomnianych książek.

\section{Porady guwernantek}

Osobną grupę tworzą książki napisane przez francuskie guwernantki Jeanne-Marie Leprince de Beaumont (1711-1780), Stéphanie Félicité du Crest de Saint-Aubin, hrabinę de Genlis (1746-1830) i Madame de La Fite, czyli Marie-Élisabeth de Bourée (1737 lub 1750 $\left.0^{48}-1794\right)$. Pierwsza z nich, ucząca najpierw dzieci byłego króla Polski, księcia Lotaryngii Stanisława Leszczyńskiego na dworze w Lunéville, a potem pracująca w angielskich domach, opublikowała w Londynie w 1756 roku Magasin des enfans. Już w tym samym roku książka przełożona została na języki angielski i niemiecki, a w 1768 roku ukazała się po polsku w Warszawie, u Michała Grölla, w tłumaczeniu nauczyciela u pijarów, ks. Eustachego Dębickiego, pod tytułem Magazyn dziecinny, czyli rozmowy między mądra ochmistrzynia a damami zacnego urodzenia jej powierzonemi. Ze względu na jej poczytność książkę wkrótce wznowiono (w 1774 i 1778 r.). Podobnie jak u Boccaccia, utwór podzielony jest na rozmowy i na dni, a zebrane wokół mądrej bony - jak można wnioskować z tytułu, wyraźnie określającego bohaterki, a przez to czytelniczki - dziewczynki (około dwunastoletnie), wychodząc od lektury czy wydarzenia, dyskutują na różne nawiązujące do nich tematy. Inspirujące historie znajdują w Biblii (np. historia Mojżesza), w baśniach (np. Piękna i Bestia, tu spisana po raz pierwszy), opowieściach (np. o Rolandzie i Angelice) czy historiach z życia (np. o kobiecie z chorą wątrobą). Podstawowe wydają się kwestie dotyczące dobrego życia, szczęśliwości na tym i tamtym świecie, a opowieści uczą bogobojności, uczciwości,

48 Źródła podają te dwie daty. Częściej pojawia się pierwsza z nich. 
jałmużny, powściągliwości itd. Panny noszą imiona znaczące, utworzone od cech charakteru, jakie uosabiają; w oryginale na przykład Lady Babiole (Szczebiotka), Lady Spirituelle (Dowcipna), Lady Sensée (Roztropna), w polskim przekładzie zaś Innocencja, Prudencja, Palladia, ale też Karolina czy Marcella. Książka jest z ducha oświeceniowa: promuje wartości tej epoki, pochwala kształcenie i rozwój oraz odejście od dawnego sposobu wychowania. Centrum życia dziewczynek nie mają stanowić lalki, uroda, gra na instrumentach, ale książki, i to nie bajki czy romanse, lecz te dające wiedzę. W dyskursie - dość nieznośnym przez nachalny dydaktyzm - rzuca się w oczy nie tylko wszechwiedza bony, ale i autodydaktyczna postawa dzieci, ich skłonność do samooceny i samokrytycyzmu, pouczania rówieśników, w czym - co

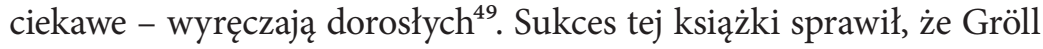
opublikował kolejne książki de Beaumont, wszystkie w tym samym przekładzie, i także szybko je wznowił: Magazyn panieński, czyli rozmowy między mądra ochmistrzynią i zacnemi damami jej ćwiczeniu poruczonemi (oryg. 1760, pol. 1770, wyd. 2 - 1775), Dokończenie Magazynu panieńskiego, czyli nauki dla dam dorosłych na świat wychodzacych [...] (oryg. 1764, pol. 1774, wyd. 2 - 1779) ${ }^{50}$. Powtarza się w nich ta sama konwencja: w drugiej części do grona starszych już uczennic dołączają nowe i pojawiają się bardziej dojrzałe tematy (m.in. relacje małżeńskie, stosunek do służby, stosunek do nieprzyjaciół), a w trzeciej - powinności stanu małżeńskiego, wychowanie dzieci itd.

Dużą popularnością cieszyły się też utwory Stéphanie Félicité du Crest de Saint-Aubin, hrabiny de Genlis, wychowawczyni dzieci Ludwika Filipa Orleańskiego. Nazywana krytycznie „guwernerem w spódnicy", miała swój oryginalny program wychowawczy, oparty między innymi na Locke’u i Rousseau ${ }^{51}$. Spośród jej licznych dzieł

49 R. Waksmund, Nie tylko Robinson..., s. 117.

50 Zob. A. Nikliborc, Od baśni do prawdy. Szkice z dziejów literatury zachodniej dla dzieci i młodzieży, Warszawa 1981, s. 32.

${ }^{51} \mathrm{O}$ teoriach edukacyjnych de Genlis i ich wpływie na polskie oświecenie zob. W. Janiec, Twórczość Stéphanie-Félicité de Genlis w Polsce, „Pamiętnik Literacki” 81 (1990), z. 4, s. 17-36. 
w Polsce wydano głównie te o tematyce religijnej (dla dorosłych i dla dzieci), a także wychowujące w bardziej rozrywkowej formie, ale zawsze czułostkowe. Przekłady ukazywały się w różnych oficynach. Także u Grölla ukazały się trzy tomy Teatru dla użytku młodych, czyli Komedii pani Genlis w przekładzie ks. Ładowskiego (oryg. 1779-1780, pol. 1787-1788). W tych samych latach Grebel wydał trzy tomy powieści Adele i Teodor, czyli listy o edukacji zawierajace w sobie wszystkie maksymy i prawidła stosowne do trzech układów edukacji: dam, mężczyzn i osób przeznaczonych do rzadu w tłumaczeniu Karoliny Czermińskiej, starościanki drohomyślskiej (oryg. 1782, pol. t. 1 i 2 - 1787, t. 3 - 1788), reklamowane w katalogu drukarni jako podręcznik dla tych trzech grup społecznych ${ }^{52}$. Z kolei warszawscy pijarzy wydali aż dwa tytuły: utwór napisany dla synów „Księcia Aureliańskiego ${ }^{53}$ " O religii uważanej jako jedynej szczęśliwości i prawdziwej filozofi zasadzie, przełożony przez ks. Franciszka Ksawerego Dmochowskiego (oryg. 1787, pol. 1789), oraz niezwykle popularne, także trzyczęściowe Wieczory zamkowe, albo ciąg nauki obyczajów do pojęcia młodzi przystosowany, przetłumaczone przez ks. Kajetana Skrzetuskiego (oryg. 1784, pol. t. 1 - 1786, wyd. 2 - 1789, t. 2 - 1790, t. 3 - 1791). Ostatnia z książek, mimo przeznaczenia dla młodych czytelników, była powszechnie czytana, a informacje o historii sztuki, zamieszczone w tomie 3 , stanowiły dla wielu podstawowe źródło wiedzy o malarstwie, rzeźbie i muzyce ${ }^{54}$.

Madame de La Fite, trzecia z autorek-guwernantek, była wychowawczynią dzieci królewskich w Windsorze ${ }^{55}$. Po polsku, w krakowskiej

${ }_{52}$ Zob. zamieszony na końcu tomu Katalog ksiażek polskich krajowych, które wyszły z Drukarni Greblowskiej w Krakowie w 1788, w: J.B. Massilon, Kazania, t. 10, Kraków 1788, s. 2 [nlb.].

${ }^{53}$ Księstwo Aureliańskie ze stolicą w Aurelianie (łac. Civitas Aureliani), dawne określenie Księstwa Orleanu.

${ }^{54}$ B. Gubrynowicz, Romans w Polsce za czasów Stanisława Augusta, Lwów 1904, s. 53.

${ }_{55}$ P.E. Brown, A Critical History of French Children's Literature, vol. 1: 16001830, New York 2008, s. 144 i nn. 
drukarni Ignacego Grebla, ukazał się tylko jeden jej utwór - Rozmówki, komedyjki, powiastki obyczajowe dla małych dzieci (t. 1 - 1786, t. 2 - 1787), czyli przekład jej pierwszej książki Entretiens, drames et contes moraux, à l'usage des enfans z roku 1778 (wielokrotnie wznawianej za granicą - 1783, 1791, 1796, 1801, 1820). Tłumaczem tomów jest zapewne ks. Antoni Prokopowicz, gdyż jego nazwisko figuruje na początku tomu 1 pod podziękowaniami dla sponsorującej wydanie hrabiny Ankwiczowej. Książka - jak czytamy w przedmowie Do czytelnika ${ }^{56}$ została napisana dla mniejszych dzieci, które jeszcze nie potrafią czytać dłuższych, a przez to nużących, opowieści pani de Beaumont. Także ten zbiór napisany jest w formie rozmowy (w tomie 1 jest 14 rozmówek) między matką a jej córką i siostrzenicą, które w polskim przekładzie noszą zdrobniałe imiona Julisia i Annulka, i przeznaczony jest raczej dla czytelnika dziewczęcego. Matka, odpowiadając dziewczynkom na ich pytania, wymyśla historyjki, które niejednokrotnie mają formę bajki czy opowiastki (jak o Fryderyku i Danielu) lub teatralnego dialogu jak w teatrzyku (rozmowa Helusi i Cecylki). Niekiedy rozrywką i ilustracją jakiejś nauki są „komedyjki”, między innymi Doświadczenie miłości synowskiej, którego bohaterami są Karol i Guilelm, ich ojciec, wuj i kupiec, a podstawową kwestią jest ustalenie, który z synów naprawdę kocha ojca, zwłaszcza w obliczu będącej sprawdzianem utraty majątku. Inne to na przykład Miłość braterska czy Zbieraczka kłosów; co ciekawe, obydwa te utwory - według słów bohaterek - są przez nie przetłumaczone: pierwsza przez matkę, a druga (co zaskakujące!) przez małą Julisię. Także w zbiorze Madame de La Fite widoczny jest układ szkatułkowy, rama i kolejne historie umieszczane w historiach. W tematach rozmowy bohaterek, opowieściach i formie odpowiedzi powraca nieustannie motyw zabawy, wskazujący na wiek bohaterów i czytelników, a także na typowe dla oświecenia łączenie zabawy i nauki. Tom 1 kończy List Julisi do Anulki ${ }^{57}$, w którym ta zdradza,

${ }^{56}$ Jest on podpisany inicjałami R.O.

$57 \mathrm{~W}$ tomie tym, jak i często $\mathrm{w}$ innych w tym czasie, pojawia się różna pisownia, na przykład Annulka i Anulka, Guilelm i Gwilelm itd. 
że jest autorką książki, to ona bowiem spisała ich rozmowy i nauki, a poprawki naniosła mama. $\mathrm{W}$ ten sposób z jednej strony wskazuje się na słuszność metod wychowawczych matki i autodydaktyzm dzieci, a z drugiej - na rolę matki jako mentorki ${ }^{58}$ nie tylko w wychowaniu, ale i twórczości literackiej.

Utwory wszystkich trzech wychowawczyń młodego pokolenia wynikają z ich guwernerskiej praktyki i przyjmują kilka klasycznych form: dyskursu młodych skupionych wokół mentora, nauczycielki (jak w kolejnych Magazynach) czy matki (jak w Wieczorach czy Rozmówkach...), pouczających listów oraz lubianych w szkołach pijarów czy jezuitów teatrów. Wykład o religii jest z kolei nawiązaniem do dawnej literatury elitarnej, pisanej dla dzieci książęcych; teraz upowszechnianej. Popularność tego typu autorek wynikała ze zwyczaju kształcenia dzieci w bogatych domach przez francuskich guwernerów; teraz ich funkcję miały przejąć książki. W tej sytuacji zastanawia jednakże ich przekład, który zapewne nie wiązał się z dotarciem do uczniów francuskojęzycznych (wszak publikacje te mogły w oryginale stanowić dodatkowy materiał dydaktyczny), ale do czytelników polskojęzycznych. Warto zauważyć, że większość tych utworów została wydana $\mathrm{w}$ drukarniach warszawskich, z przewagą Grölla, a dwa tytuły w Krakowie, wszystkie w latach 70., 80. i 90. XVIII wieku, przy czym polskie przekłady ukazywały się dość szybko, kilka lat po oryginałach. Natrętnie moralizatorskie, często naiwne i uczuciowe, na długi czas określiły pewien typ literatury dla dziewcząt. Jeszcze w 1821 roku Komisja Oświecenia zalecała utwory de Beaumont do użytku w pensjach żeńskich, dopiero w latach 70 . XIX wieku uchodziły za anachronizm ${ }^{59}$.

58 O roli mentora zob. „Filoteknos” 7 (2017), tu między innymi R. Waksmund, Uźródeł postaci mentora $w$ polskiej literaturze dziecięcej.

${ }^{59}$ Opinia między innymi o tomie Czarodziejskie baśnie (1879) z fragmentami utworów de Beaumont w przekładzie Karoliny Gościmskiej. Zob. I. Kaniowska-Lewańska, Literatura dla dzieci i młodzieży..., s. 29. 


\section{Francuscy i niemieccy przyjaciele dzieci}

Wiek XVIII, obok klasycznej postawy mentora i wychowawcy, przyniósł też inną, nowatorską - przyjaciela dzieci. Znalazło to odbicie w piśmiennictwie dla najmłodszych, najpierw w czasopismach, a potem w ich książkowych wydaniach. Do popularności tego podejścia i samego określenia przyczynił się magazyn "L’Ami des Enfants”60, ukazujący się w Paryżu od stycznia 1782 do grudnia 1783 roku (24 numery), wydawany przez Arnauda Berquina (1741-1791), zwanego odtąd „przyjacielem dzieci”. Czułostkowe i sielankowe historie umoralniające, opowiadane przez dorosłych „przyjaciół”, zostały wydane w Londynie w 1783 roku, a rok później Berquin otrzymał za nie nagrodę Akademii Francuskiej za najużyteczniejsze dzieło ${ }^{61}$. To pierwsze wydanie było klasyczne, skromne, z winietą, frontyspisem, kolejne tomy i liczne wznowienia już ilustrowane, $\mathrm{z}$ coraz bogatszą szatą graficzną. Nie ma pewności co do tego, kiedy ukazało się pierwsze polskie wydanie. Kaniowska-Lewańska, a za nią inni badacze, podaje lata 1782-1786, a jako tłumaczkę Annę Narbutównę (pisaną przez jedno „t” ${ }^{62}$. Tymczasem Nowy Korbut w tomie 5 takiej osoby nie odnotowuje, jedynie Aleksandrę Narbuttównę oraz Annę Grozman Narbuttową ${ }^{63}$, tłumaczki zupełnie innych utworów. Zresztą

60 Tytuł wziął z traktatu pedagogicznego Guillaume’a Grivela L’Ami des jeunes gens (1762). Por. A. Nikliborc, La littérature française pour la jeunesse en Pologne au siècle des Lumières, w: La littérature des Lumières en France et en Pologne. Esthétique. Terminologie. Échanges, éd. J. Heistein, Warszawa 1976. Warto sięgnąć też do innych opracowań tej autorki na temat literatury francuskiej: A. Nikliborc, Francuska książka dla dzieci i młodzieży w wieku oświecenia (Studia o Książce, t. 7), Wrocław 1977; A. Nikliborc, Z dziejów literatury dziecięcej. Początki literatury dla dzieci we Francji, w: O literaturze dla dzieci i młodzieży. Studia i szkice, red. H. Skrobiszewska, Warszawa 1975.

${ }^{61}$ Berquin (Arnaud), w: Dykcjonarz biograficzno-historyczny, czyli Krótkie wspomnienia żywotów ludzi wsławionych cnotą, nauką..., t. 1, Warszawa 1844, s. 141.

${ }^{62}$ Zob. I. Kaniowska-Lewańska, Literatura dla dzieci i młodzieży..., s. 33.

${ }^{63}$ Chorążyna powiatu lidzkiego (mąż targowiczanin), tłumaczka między innymi Diabła kulawego Le Sage’a. Zob. J. Rudnicka, Ostatnio zidentyfikowane prze- 
Narbuttowa w 1786 roku zaczęła tłumaczenie Teatru dziecinnego Berquina, który potem ukazał się w Wilnie u pijarów w 1802 roku $^{64}$; może stąd przeniesienie. Z kolei Kalina Bartnicka podaje, że przekład ten wykonała autorka i pedagog Anna Nakwaska ${ }^{65}$. Na pewno istnieje wydanie lwowskie tego utworu, u Józefa Jana Pillera z lat 1819-1820, w czterech tomach w przekładzie Anieli z ks. Sapiehów Jelskiej, która dedykowała je swoim wnukom ${ }^{66}$; osiemnastowieczne nie jest pewne. $\mathrm{Z}$ tego wieku w bibliografii Estreichera pojawia się jako tłumaczony $\mathrm{z}$ „Berkina” Prawdziwy przyjaciel dzieci gruntownemi maksymami i przyzwoitemi ich wiekowi i pięciu bajeczkami do doskonałości prowadzacy, wydany w Wilnie w 1777 lub 1778 roku $^{67}$. Jest to jednak oczywisty błąd (polski przekład byłby wcześniejszy niż oryginał!), nie jest to przekład z Berquina, ale niemieckiego utworu ks. Józefa Reyre’a, wykonany przez ks. Jakuba Petrusewicza.

Zamieszanie w tytułach, autorach i datach wywołane jest zarówno niekompletnymi danymi w wydaniach, jak i powszechnym używaniem w owym czasie w tytułach określenia „przyjaciel dzieci”, którego zresztą nie wymyślił Berquin (choć je rozpowszechnił). Najpierw pojawiło się ono w tytułach niemieckich czasopism dla dzieci, między innymi w przeznaczonym dla dzieci mieszczańskich „Der Kinderfreund" przyjaciela Lessinga, poety Christopha Felixa Weissa (1775-1784). Pierwszy tom wydania polskiego Przyjaciel dzieci dzieło tygodniowe oryginalnie w języku niemieckim przez pana Weissa wydane, na polski przettumaczone dla zabawy i domowej edukacji dzieci bardzo użyteczne, w przekładzie żony starosty inflanckiego Izabeli Plater z pomocą jej trzech synów, ukazał się nakładem własnym

kłady powieści francuskich w Polsce w. XVIII, „Pamiętnik Literacki” 54 (1963), z. 3, s. $117-126$.

${ }^{64}$ Zob. „Kurier Litewski” 51 (25.06.1802), s. 2.

${ }^{65}$ K. Bartnicka, Dziecko w świetle pamiętników i powieści polskiego Oświecenia, „Rozprawy z Dziejów Oświaty” 35 (1992), s. 85.

${ }^{66}$ J. Sowiński, O uczonych Polkach, Krzemieniec 1821, s. 141.

${ }^{67}$ K. Estreicher, Bibliografia polska, t. 12, Kraków 1891, s. 510. Później ten błąd został poprawiony. 
w Warszawie w Drukarni Księży Misjonarzy w 1789 roku, a kolejne cztery tomy ( $\mathrm{z}$ dwunastu) do 1792 roku $^{68}$. Wydanie oryginalne posiadało nieliczne ilustracje miedziorytowe związane tematycznie z książką, na stronie tytułowej i wewnątrz, frontyspis, a także nuty, zaś polskie było uboższe, bez nut, a jedynymi elementami zdobniczymi były winiety nagłówkowe i finalikowe oraz linie ozdobnikowe. Poczyniono też poprawki w tekstach o charakterze religijnym oraz zmieniono bohaterom niemieckie imiona na polskie. Także tutaj dorośli mężczyźni występują w roli kochających dzieci i kochanych przez nich przyjaciół. Uderza naiwność ujęcia: tak jak u de Beaumont dziewczynki same się pilnowały i pouczały, tak tutaj dzieci są głodne towarzystwa dorosłych i wręcz dopraszają się opowieści i wiedzy z geografii, historii, poezji, historii naturalnej, etyki i religii. Nauk udziela im krzepki staruszek Filoteknos (z gr. kochający dzieci), opowiadający bajki i historyjki oraz przynoszący słodycze i obrazki, pan Papillon - przyrodoznawca, dr Kronikel - znawca historii i pan Spryt - miłośnik sztuk pięknych.

Pojawił się także tom w podobnej formule przeznaczony dla dzieci chłopskich: Przyjaciel dzieci, to jest książka do czytania i używania [...] pierwej po niemiecku napisana [...] (oryg. 1776 i 1779, pol. Królewiec 1795) Friedricha Eberharda von Rochowa (1734-1805), niemieckiego magnata i pedagoga, a przetłumaczony przez ks. Jerzego Olecha, proboszcza parafii polsko-ewangelickiej. Ten niezwykle popularny podręcznik szkół ludowych miał na celu propagowanie myśli oświeceniowej w powiązaniu z założeniami pruskiej polityki wychowawczej, stąd w czytankach znalazły się zarówno informacje o świecie, zjawiskach fizycznych, przyrodzie, pogodzie, medycynie czy religii, z jednoczesną krytyką guseł i zabobonów, zasady uprawy i hodowli,

68 B. Łaszewska-Radwańska, „Przyjaciel Dzieci” Christiana Feliksa Weissego. Zagadnienia autorstwa, przekładu i wydania polskiego z lat 1789-1792, „Acta Universitatis Wratislaviensis. Bibliotekoznawstwo” 1998, t. 21, s. 131-146; eadem, „Przyjaciel Dzieci" Chrystiana Feliksa Weissego - przekład polski czasopisma w edycji warszawskiej z lat 1789-1792, w: Młody czytelnik w świecie książki, biblioteki i informacji, red. K. Heska-Kwaśniewicz, I. Socha, Katowice 1996, s. 34-41. 
jak i kwestie dotyczące wychowania dzieci na dobrych pracowników dla dworu oraz pochwała militarnej potęgi Prus. Określenie „przyjaciel dzieci" i owo ujęcie rozpowszechniło się w Polsce tak bardzo, że w XIX wieku pod takim tytułem ukazywało się około 18 czasopism.

\section{Wzorce dla wiejskich chłopców}

Ksiądz Jerzy Olech zdominował wydawanie przekładów z języka niemieckiego mających służyć nauce, wychowaniu i rozrywce dzieci chłopskich. Kolejne dwie przetłumaczone przez niego książki, także wydane w Królewcu, to opowieści autorstwa turyńskiego księdza i pedagoga Christiana Gotthilfa Salzmanna, mające służyć za wzór czytającym je wiejskim chłopcom. Sebastian Mądry. Książka dla pospólstwa (oryg. 1790, pol. 1799) opowiada o losach czternastoletniego chłopca pochodzącego z biednej i zacofanej rodziny, żyjącego w brudzie i lenistwie, tak jak jego rodzice. Pan Dobroczyński, światły obywatel o znaczącym nazwisku, wskazuje chłopcu dobrą drogę, robi z niego oświeconego, uczciwego, pracowitego i nowoczesnego włościanina, męża i obywatela oraz pomaga w założeniu własnego gospodarstwa. Podobną strukturę ma utwór Konstantego ciekawa albo wiedzenia godna historia życia i osobliwe jego przypadki. Ksiegga dla pospólstwa, osobliwie dla rzemieślniczych towarzyszów, czyli pachołków (oryg. 1791, pol. 1800), zawierający nauki dla synów mieszczańskich.

\section{Pouczające książeczki pana Campego}

Wielką popularnością także w Polsce cieszyły się utwory Heinricha Joachima Campego (1746-1818), niemieckiego filantropisty, pedagoga prowadzącego własny zakład wychowawczy, nauczyciela Wilhelma i Alexandra Humboldtów. Najwcześniej, w 1779 roku, we Wrocławiu u Jana Bogumiła [Johanna Gottlieba] Korna ukazała się Książeczka moralna dla dzieci od Imci Pana Kampe po niemiecku napisana teraz 
zaś na ojczysty język przełożona; tłumacza nie podano. W kolejnej edycji (we Wrocławiu i w Lisie w Prusach) z 1800 roku jako tłumacz figuruje S. Stawski ${ }^{69}$. Bohaterem książki skierowanej do „dzieci kochanych” jest cnotliwy 70-latek Bogumił Czcigodnicki ${ }^{70}$, który na prośbę sąsiada Andrzeja Dobrocheckiego postanawia opowiadać dzieciom różne historie i tak je uczyć. W utworze napisanym w duchu sentymentalnym dzieci z zaskakującym entuzjazmem porzucają więc swoje zabawy i chłoną podczas czterech kolejnych wieczorów nauki o cnotach, powinnościach, grzechach, przywarach, religii, nierzadko się przy tym wzruszając. Podobną tematykę, choć w formie wykładu, mają wydane w Warszawie w 1788 roku Wiadomości początkowe o duszy ludzkiej do pojęcia młodzi stosowane w niemieckim języku napisane przez J.H. Campe [...]; nie znamy ani tłumacza, ani wydawcy.

W 1793 roku, nakładem F.Ch. Netto, na Krakowskim Przedmieściu wydano w dwóch tomach jedną z najpopularniejszych książek Campego, która zapoczątkowała w Niemczech rozwój literatury dla młodzieży, a mianowicie dydaktyczną przeróbkę dla dzieci książki Defoe Nowy Robinson, dzieło dla zabawy i nauki dzieci (oryg. Robinson der Jungere [1779]) $)^{71}$. Ukazała się ona w 1795 roku we Wrocławiu u Guilielma Bogumiła vel Wilhelma Bogumiła [Wilhelma Gottlieba] Korna, potem w roku 1809; po 1830 roku tytuł przejęli wydawcy warszawscy. Co ciekawe, przekład nie pochodził z oryginału, ale był zapośredniczony, o czym informowano w podtytule (podług niemieckiego oryginału P. Campe z francuskiego wyłożone), a (niewymieniony z nazwiska) tłumacz w przedmowie zamieścił dodatkowo pochwały Rousseau. Przeróbka, bardzo niemiecka (Hamburg, XVI w.) i mieszczańska, z ducha protestancka, jest zbudowaną na schemacie baśniowym powieścią o pracy, w której Robinson (Niemiec!),

${ }^{69}$ Wydania zawierały wiele błędów, które starano się eliminować w kolejnych edycjach. W XIX wieku wydawane przez Pillerów.

${ }^{70}$ W oryginale (Sittenbüchlein für Kinder aus gesitteten Ständen, 1777) nazywa się Gottlieb Ehrenreich, przekład wiernie oddaje więc zamierzenie autora.

71 W ciągu 11 lat ukazało się 21 wydań, tłumaczenia na wszystkie języki europejskie. 
najmłodszy z trzech synów i obibok, ucieka z domu, a wszystko, co go spotyka w podróży, jest karą zesłaną przez Opatrzność. Wreszcie przychodzi po rozum do głowy, odpokutowuje i wyciąga z błędów naukę: jedyne szczęście jest w życiu rodzinnym, a wychowanie młodego pokolenia służy szczęściu wspólnemu.

Myśl tę powtarzał Campe jeszcze w innych swych dziełach napisanych dla młodzieży, a ukazujących męskie wzorce na przykładzie wypraw znanych podróżników. Kontynuacja historii Robinsona z 1781 roku ukazała się jako tom 3 we Wrocławiu u W.B. Korna dopiero w 1809 roku pod tytułem Odkrycie Ameryki. Dzieło przeznaczone do oświecenia i zabawy młodzieży a składajace dalszy ciag Nowego Robinsona; wiele razy była wznawiana. I tu podczas kolejnych wieczorów ojciec, cnotliwy i światły, postanawia opowiedzieć zebranym wokół niego dzieciom o Kolumbie i w ten sposób - jak pisze autor - dostarczyć im w czasie miłych rozmów, niemających pozorów nauki - wiadomości pożytecznych i przyjemnych. Osobne utwory, poświęcone Pizarrowi czy Cortésowi, ukazały się po polsku dopiero w XIX wieku ${ }^{72}$, ale tematyka ta pojawia się w dwóch kompilacjach z Campego. W Warszawie u Grölla w 1789 roku ukazała się Historia odkrycia Ameryki przez Kolumba, wynalezienie Meksyku przez Kortesa, podbicie Peru przez Pizarra $^{73}$ w tłumaczeniu Jacka Jezierskiego, kasztelana łukowskiego, a w 1794 roku w krakowskiej drukarni Jana Maya wydano Zbiór podróży ważnych i ciekawych dla nauki i zabawy młodych tłumaczony z zbioru podróżów pana Campe i innych w przekładzie Stanisława Szymańskiego, konsyliarza nadwornego ${ }^{74}$. Co ciekawe, w tym drugim tomie z Campego w gruncie rzeczy pochodzi tylko początek, a większość stanowią owi „inni” autorzy. Wiele utworów tego popularnego autora wydano już w wieku XIX, po czym ze względu na nieprzystosowanie do polskich warunków i potrzeb wznowień zaniechano.

${ }^{72}$ J.St. Buras, Bibliographie deutscher Literatur in polnischer Übersetzung: vom 16. Jahrhundert bis 1994, Wiesbaden 1996, s. 98-101.

73 Estreicher nie notuje.

${ }^{74} \mathrm{~W}$ innym przekładzie, pod innym tytułem wydawany w XIX wieku u Jana Fryderyka [Johanna Friedricha] Korna. 


\section{Rodzicielskie rady i pouczenia}

W XVIII wieku ukazywały się także osadzone w kulturze domowej pozycje napisane w formie rodzicielskich porad dla synów i córek. Były to tłumaczenia: na przykład przełożone z niemieckiego przez nadwornego kaznodzieję Ignacego Witoszyńskiego Napomnienia na piśmie dane od ojca synowi przy wysyłaniu go na nabywanie nauk do akademii autorstwa Christiana F. Gellerta (Wilno: Drukarnia Akademicka, 1781) albo przetłumaczone $\mathrm{z}$ francuskiego przez podkomorzankę krakowską Teodorę Walewską dwa utwory zamieszczone w tomie Ostatnie słowo konającego ojca do syna. List umierajacej matki do córki swojej (wyd. 1 w Krakowie u Grebla - 1783, wyd. 2 - 1785; brak autora). W obydwu utworach życiowe rady udzielane są potomkom w wyjątkowych momentach wchodzenia w dorosłe życie: wyjazdu do szkół (syn) i w chwili utraty rodzica (córka), adekwatnie do ich miejsca w ówczesnym społeczeństwie. Forma porad rodzicielskich była niezwykle popularna wśród osiemnastowiecznych utworów na Zachodzie, w Polsce moda na nie przyszła dopiero z początkiem XIX wieku, prócz przekładów zaczęto też wówczas pisać podobne utwory po polsku.

Książka dla dzieci i młodzieży w XVIII wieku wciąż jest edytorsko i treściowo zależna od tej dla dorosłych i z nią w różny sposób powiązana, a osobny rynek tego typu literatury jeszcze nie istnieje. Książki dla młodych wydawane są we wszystkich większych drukarniach na ziemiach polskich z przewagą Warszawy. Można zauważyć jednak pewne tendencje wydawnicze, na przykład książki francuskich guwernantek ukazują się u Grölla, dla dzieci wiejskich w Królewcu, przekłady z niemieckiego najczęściej we Wrocławiu itd. Literatura dla najmłodszych dopiero zaczyna kształtować swoją osobność, lecz jest pod przemożnym wpływem pedagogiki w duchu oświeceniowym i wytworzonego przez epokę obrazu dziecka; wciąż widoczne są także elementy dawnego, tradycyjnego, „chrześcijańskiego” wychowania. Książka przejmuje rolę guwernera, mentora, przyjaciela dzieci, opiekuna, rodzica i stara się 
wprost lub przez bardziej lub mniej subtelną rozrywkę przekazać wiedzę, wskazać właściwe wzorce, naprowadzić. Dzieci i młodzież w niej przedstawione są zaś otwarte na kształtowanie, chętne, wrażliwe, podatne i przyjmują nauki oraz porady z wdzięcznością, rezygnując bez żalu z zabawy na rzecz wejścia w dorosłość, niejednokrotnie autodydaktycznie pilnując siebie i rówieśników. Literatura miewa charakter encyklopedyczny, publicystyczny, często na pograniczu podręcznika

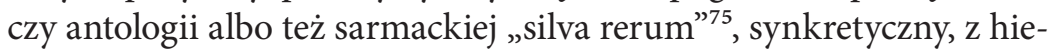
rarchią gatunków podporządkowanych oświeceniowym ideom. Osiemnastowieczna oświeceniowa książka dla dzieci i młodzieży to zawsze publikacja pożyteczna, obyczajna, stosowna i ucieszna. To także książka uniwersalna, nie tylko przez wielotematyczność i wielofunkcyjność ${ }^{76}$, ale też przez to, że wiele z lektur trafiających wówczas w ręce młodych czytelników przynależy do szerokiego kręgu odbiorców.

\section{Bibliografia}

Aleksandrowska E., „Zabawy Przyjemne i Pożyteczne” 1770-1777. Monografia bibliograficzna, Warszawa 1999.

Ariès P., Historia dzieciństwa, przeł. M. Ochab, Warszawa 2010.

Bartnicka K., Dziecko wświetle pamiętników i powieści polskiego Oświecenia, „Rozprawy z Dziejów Oświaty" 35 (1992).

Bednarska-Ruszajowa K., Uczyć - bawić - wychowywać. Książka i jej funkcja społeczna w Polsce w okresie Oświecenia, Kraków 2004.

Berquin (Arnaud), w: Dykcyonarz biograficzno-historyczny, czyli Krótkie wspomnienia żywotów ludzi wsławionych cnota, nauka [...], t. 1, Warszawa 1844.

Brown P.E., A Critical History of French Children's Literature, vol. 1: 1600-1830, New York 2008.

Buras J.St., Bibliographie deutscher Literatur in polnischer Übersetzung: vom 16. Jahrhundert bis 1994, Wiesbaden 1996.

Dunin J., Książeczki dla grzecznych i niegrzecznych dzieci. Z dziejów publikacji dla najmłodszych, Wrocław 1991.

Estreicher K., Bibliografia polska, t. 12, Kraków 1891.

75 R. Waksmund, Nie tylko Robinson..., s. 110, 154.

${ }_{76}$ Tak rozumie ją Waksmund, ibidem. 
Estreicher K., Bibliografia polska, t. 21, Kraków 1906.

Gubrynowicz B., Romans w Polsce za czasów Stanisława Augusta, Lwów 1904.

Janiec W., Twórczość Stéphanie-Félicité de Genlis w Polsce, „Pamiętnik Literacki” 81 (1990), z. 4.

Kaniowska-Lewańska I., Literatura dla dzieci i młodzieży do roku 1864, Warszawa 1980.

Katalog książek polskich krajowych, które wyszły z Drukarni Greblowskiej w Krakowie w 1788, w: J.B. Massilon, Kazania, t. 10, Kraków 1788.

Konieczna J., Rynek wydawniczy książki dziecięcej w zaborze rosyjskim w XIX i w początkach XX wieku, „Sztuka Edycji” 1 (2013).

Korzo M.A., Elementa Pverilis Institutionis (Kraków 1692) - przyczynek do historii elementarzy polskich, „Biblioteka” 20 (2016).

„Kurier Litewski” 51 (25.06.1802).

Łaszewska-Radwańska B., „Przyjaciel Dzieci” Chrystiana Feliksa Weissego - przekład polski czasopisma w edycji warszawskiej z lat 1789-1792, w: Młody czytelnik w świecie książki, biblioteki i informacji, red. K. Heska-Kwaśniewicz, I. Socha, Katowice 1996.

Łaszewska-Radwańska B., „Przyjaciel Dzieci” Christiana Feliksa Weissego. Zagadnienia autorstwa, przekładu i wydania polskiego z lat 1789-1792, „Acta Universitatis Wratislaviensis. Bibliotekoznawstwo" 1998, t. 21.

Nikliborc A., Francuska książka dla dzieci i młodzieży w wieku oświecenia (Studia o Książce, t. 7), Wrocław 1977.

Nikliborc A., La littérature française pour la jeunesse en Pologne au siècle des Lumières, w: La littérature des Lumières en France et en Pologne. Esthétique. Terminologie. Échanges, éd. J. Heistein, Warszawa 1976.

Nikliborc A., Od baśni do prawdy. Szkice z dziejów literatury zachodniej dla dzieci i młodzieży, Warszawa 1981.

Nikliborc A., Z dziejów literatury dziecięcej. Początki literatury dla dzieci we Francji, w: O literaturze dla dzieci i młodzieży. Studia i szkice, red. H. Skrobiszewska, Warszawa 1975.

Rudnicka J., Ostatnio zidentyfikowane przekłady powieści francuskich $w$ Polsce w. XVIII, „Pamiętnik Literacki” 54 (1963), z. 3.

Rzadkowska E., Francuskie wzorce polskich oświeconych. Studium o recepcji J.F. Marmontela w XVIII w., Warszawa 1989.

Sinko Z., Powieść angielska osiemnastego wieku a powieść polska lat 1764-1830, Warszawa 1961.

Sinko Z., Powieść zachodnioeuropejska w kulturze literackiej polskiego oświecenia (Studia z Okresu Oświecenia, t. 8), Wrocław 1968.

Skwarczyński Z., „Podróże napowietrzne” Juliana Ursyna Niemcewicza, „Prace Polonistyczne" 21 (1965), s. 70-79.

Smuszkiewicz A., Literatura dla dzieci, Poznań 2015.

Sowiński J., O uczonych Polkach, Krzemieniec 1821.

Waksmund R., Nie tylko Robinson, czyli o oświeceniowej literaturze dla dzieci i młodzieży, Warszawa 1987. 
Waksmund R., U źródet postaci mentora w polskiej literaturze dziecięcej, „Filoteknos" 7 (2017).

Wojnarowska A., Kultura i literatura. O genezie i rozwoju polskiej literatury dla najmłodszych, http://www.bwmp.up.krakow.pl/wp-content/uploads/2016/10/ Wojnarowska.pdf (dostęp: 11.03.2019).

Zarych E., Ilustracje dla dzieci, encyklopediadziecinstwa.pl (dostęp: 10.03.2019). Żbikowska-Migoń A., Dzieje książki i jej funkcji społecznej. WiekXVIII, Wrocław 1987. Пазднякоў В., Асухоўскі Мялецій (Ossuchowski Melecjusz), w: ВКЛ энцъьклапедыя, http://vkl.by/articles/2307 (dostęp: 30.08.2019). 